\title{
About the Organization of the Customs Service at the Mesolevel
}

\author{
Roman V. Fedorenko' \\ Sovetskoi Armii Str. 141, Samara, 443090, Russian Federation; Email: fedorenko083@yandex.ru \\ Lilyana A. Sosunova ${ }^{1}$ \\ Elena R. Khramtzova² \\ ${ }^{1}$ Samara State University of Economics, Russian Federation \\ ${ }^{2}$ Samara State Agricultural Academy, Russian Federation
}

Doi:10.5901/mjss.2015.v6n6s3p301

\section{Abstract}

The article defines the role and significance of customs services in foreign economic activities. The actuality of the problem of customs services development is stipulated by the necessity to develop foreign economic activity of any country. The existing system of customs services in foreign economic activities in the Russian Federation is estimated in the work and the problems of its functioning are revealed. The goal of the research is to define the directions of the customs services system development. On the basis of multi-level approach we can single out macro-, micro- and mezolevels of the organization of customs services and give the characteristics of the activities of subjects of different customs space levels. We focus on the necessity to develop the customs infrastructure on mezolevel, the main elements of which are professional customs mediators providing effective interaction between the participants of foreign economic activities and the customs bodies. As the result of the research we can substantiate the expediency of formation of a complex mezosystem of customs services which will unite customs bodies and organizations dealing with export-import operations and professional customs mediators.

Keywords: Foreign economic activities, customs services, mezolevel, customs infrastructure.

\section{Introduction}

The international science and practice it is stated that providing of the stable economic growth of a country is one of the important functional imperatives for the activities of customs bodies of any country. In the document of the World Customs Organization (WCO) «Customs in XXI Century: Intensification of growth and development by way of simplifying trade procedures and borders security » the global mission of the Customs is defined as the developmentr and use of integrated complex of measures and procedures providing the increase of protection and security, effective support of trade and collection of income for the state budgets (WCO, 2008).

Customs duties are the integral part of the budget of the Russian Federation. According to the data of the Ministry of Finance the income from the foreign economic activities administrated by the customs bodies make up $50 \%$ of the budget.

It is necessary to point out that the concept of trade facilitation lies in the basis of numerous initiatives on the level of international organizations and customs bodies of different countries. Trade facilitation is the main item for discussion at different rounds of negotiations within the frame of the World Trade Organization (WTO) it is often mentioned in the programmes of development of international supply chains and is the objective function of many customs services modernization programmes (Grainger, 2008).

The significance of the development of customs services is highlighted in the works of Russian and foreign scientists.

In the research works of the Organization of Economic Cooperation and Development (OECD) it is stated that customs and administrative procedures make a strong impact on the international trade. In some works it is mentioned that for some developing countries cumbersome customs and administrative procedures become the main obstacle on the way to increasing the volume of trade with other countries (Wilson, 2007).

According to the data of OECD 1\% cutting of transaction costs in foreign economic activities (FEA) will provide the worldwide profit of 43 milliard dollars (Sandford, I \& Temby, I, 2010). 
According to the research published recently in the international journal of international trade and economic development, $10 \%$ cutting of costs connected with import (export) leads to approximately $5 \%$ increase of import (export) (Hoekman, B \& Nicita, A, 2010).

The general questions of normative costs formation are studied in detail in scientific literature. These are primarily the costs connected with the tax legislation compliance. The costs connected with the customs norms compliance are less studied.

In the sphere of taxation normative costs connected with the legislation compliance are defined as costs that taxpayers bear in the process of fulfillment of responsibilities according to the tax legislation. In the research works of foreign economists the importance of such costs is highlighted. For example, in Great Britain in 2006 such costs concluded $£ 5,1$ milliard, approximately $0,45 \%$ of the British GDP. The costs connected with customs norms compliance amounted to $£ 793$ million or $15 \%$ from all additional costs connected with tax legislation compliance (Chris Evans, 2003). The situation in Great Britain is considered characteristic for the developed countries.

Some western scientists think that temporary expenditures of enterprises engaged in foreign economic activities are an important factor the improvement of which can give a company a competitive advantage (Li, Y \& Wilson, JS 2009).

The development of customs services makes a strong impact on the possibility of achievement of market success of imported or exported goods. In case of the absence of modern customs services, especially in case of long customs clearance or improper storage of goods they can partially or completely lose their consumer value and competitiveness and as a result be rejected by the consumer (Ershov A.D., Dolya, 2005).

The problems of foreign activities management are researched in detail in the works of different authors. Customs services to the participants of foreign economic activities are studied separately (Gupanova, 2011) as well as the services of specialized mediators (Fedorenko, 2014). But the questions of organization of the system of customs services uniting the activities of the customs and the providers of services in the customs sphere are not yet studied to full extent.

The literature on Economics traditionally divides the research of economic phenomena into two levels: macro- and micro-. Both the classical authors of Economic Theory and modern economists think that such division is rather conditional and there is a border area between microlevel and macrolevel which unites these two polar opposites and having the characteristics of (Macconell K.R., Bru S.L., 1992). This border area is defined as mezoeconomics. It is becoming more and more important.

Studying the problems of regional economy plays a special role in mezoeconomics as it is an important component of the national economy in general. Successful organization of foreign economic activities is very important either for the development of the national economy or the development of each region. It provides the increase of competitiveness of the territory stipulated by the level of development of customs services.

The formation of the modern customs system in conditions of territorial dispersion of enterprises-participants of foreign economic activities on the definite stage of development led to the regional localization of their customs servicing and to the concentration of the main functional of the customs activities within the frames of the regions, that is on mezolevel.

\section{Method}

The methodological basis of the research is composed by general scientific methodological approaches such as system and structure approach, cause and effect approach, situational approach, comparative approach, economics and statistics approach, factor analysis, methods of economic, mathematical and logical modeling, synthesis and decomposition, multilevel complex approach and graphical methods.

The research is based on the use of the dialectical method of cognition, methodology of the general theory of statistics as well as the complex approach to studying the subject of the research, instrumental economic methods and means.

The informational base of the research includes the data of the World Bank, the World Customs Organization and the Organization of Economic Cooperation and Development.

\section{Results}

\subsection{The Significance of the Organization of Customs Services for the Development of Foreign Economic Activities}

As Russia integrates in the world economy and enters WTO, the development of foreign economic ties is becoming more and more important for the economy of the country. 
Formation of customs services as a complex system makes it possible for the companies engaged in export-import activities to choose the most optimal variant of transportation of goods across the border, making customs clearance, passing customs control and fulfill other requirements of the customs legislation.

The understanding of the importance of customs services in the Russian Federation is reflected in the Strategy of Development of the Federal Customs Service (FCS) adopted by the Government of the RF up to 2012 in which maximum assistance to foreign economic activities on the basis of improvement of quality and successfulness of customs administration is called one of the main goals.

An important direction of FCS activities improvement in the near future is cutting costs of the participants of foreign economic activities. In advanced foreign practices progressive principles of servicing participants of foreign economic activities on the basis of partnership of business and customs bodies are used. They provide high efficiency of foreign economic activities. Unfortunately using such principles is not yet characteristic for Russia.

Despite active reformation of the whole customs system the participants of foreign economic activities still have to solve a lot of problems which demands considerable time and financial expenditures. These problems include the necessity of compliance to all the requirements of the customs legislation and solving definite economic questions such as the organization of transportation and storage of goods.

Customs services aimed at the increase of commodity turnover, the development of foreign trade and correspondent increase of income of the state budget can be represented as the totality of customs services granted by the customs bodies and the services in customs sphere provided by the subjects from around-customs infrastructure.

Granting of customs services is aimed at acceleration and simplification of passing all the necessary customs procedures by the participants of foreign economic activities. As the result their financial and time expenditures must be minimized and the efficiency of work must increase. In the conditions of the economic crises which is characterized by worse interaction with usual foreign economic partners and the development of new directions of foreign economic cooperation, the improvement of customs services is one of the most actual questions of the development of foreign economic activities of Russian companies.

\subsection{Estimation of the Existing System of Customs Services}

The average annual activity of the participants of foreign economic activities is a little more than 4 million of customs declarations per year. The membership of Russian in WTO leads to the increase of the number of participants of foreign economic activities and the efficiency of their work. About 60000 employees of the Federal Customs Service maintain these (Zhigun L.A., 2013).

This number is equal to the number of employees of the USA customs service but it does not provide the same level of customs servicing of the participants of foreign economic activities as in the USA.

In conditions of the global economy it is important to have a single approach to the estimation of customs services in different countries. The efficiency of functioning of customs system influences the organization of the international trade and according to the principles of the World Bank is inverse proportional to the number of documents, time and financial expenditures of the participants of foreign economic activities. The simplicity of conducting of the international trade is an important element of the integral index of doing business calculated by the World Bank (Table 1).

Table 1 - Rating of the Indicator "International Trade" of the World, 2014 (selection)*

\begin{tabular}{|c|c|c|c|c|c|c|c|}
\hline \multirow[t]{2}{*}{ Country } & \multirow[t]{2}{*}{$\begin{array}{c}\text { Place in the } \\
\text { Rating }\end{array}$} & \multicolumn{2}{|c|}{$\begin{array}{c}\text { The necessary number of } \\
\text { documents, item }\end{array}$} & \multicolumn{2}{|c|}{$\begin{array}{l}\text { Time expenditures, } \\
\text { days }\end{array}$} & \multicolumn{2}{|c|}{$\begin{array}{l}\text { Financial expenditures on customs formalities } \\
\text { fulfillment, dollar/container }\end{array}$} \\
\hline & & Export & Import & Export & Import & Export & Import \\
\hline Singapore & 1 & 3 & 3 & 6 & 4 & 460 & 440 \\
\hline Hong-Kong, China & 2 & 3 & 3 & 6 & 5 & 590 & 565 \\
\hline Republic of Korea & 3 & 3 & 3 & 8 & 7 & 670 & 695 \\
\hline Sweden & 4 & 3 & 3 & 9 & 6 & 725 & 735 \\
\hline Ireland & 5 & 2 & 2 & 8 & 9 & 1160 & 1121 \\
\hline Estonia & 6 & 3 & 4 & 6 & 5 & 765 & 795 \\
\hline Denmark & 7 & 4 & 3 & 6 & 5 & 795 & 745 \\
\hline The UAE & 8 & 3 & 5 & 7 & 7 & 665 & 625 \\
\hline Panama & 9 & 3 & 3 & 10 & 9 & 665 & 1030 \\
\hline France & 10 & 2 & 2 & 10 & 11 & 1335 & 1445 \\
\hline The USA & 16 & 3 & 5 & 6 & 5,4 & 1224 & 1289 \\
\hline The Russian Federation & 155 & 9 & 10 & 21 & 19,4 & 2400,5 & 2594,5 \\
\hline
\end{tabular}

The selection is made by the author from the materials of the official site of the World Bank (The World Bank, 2014) 
The top ten of the rating consist of rather small countries. According to the principles of estimation of expenditures of the participants of foreign economic activities including transport expenditures on internal transportation it can be said that small territory gives advantage to such countries. In highly developed countries such as the USA customs registration is made with a minimum of documents and correspondingly minimum financial and time expenditures.

In the State Programme of the Russian Federation "The Development of Foreign Economic Activities" adopted in April 2014 an ambitious goal to achieve the 17th place in the rating of the World Bank in "International Trade" till 2018 is set. Russia lags far behind the leaders in international trade and it asks for the detailed studying of the foreign experience of organizing customs services of foreign economic activities.

\subsection{The Role of Logistics in the Organization of Foreign Economic Activities}

The development of foreign economic activities depends to a great extent on the general level of efficiency of logistics activities of the country. The common tool of the comparative analysis of this level is an integral indicator of efficiencyLogistics Performance Index (LPI) used by the World Bank. The main components of this indicator are:

- logistics competence;

- customs;

- infrastructure;

- tracking \& tracing;

- international shipments;

- timeliness.

For the first time the rating was made in 2007 году and Russia occupied the $99^{\text {th }}$ place in it. In 2012 it occupied the 95 $5^{\text {th }}$ position and in 2014 - the $90^{\text {th }}$ (The World Bank, 2015). The main indicators of LPI index of the Russian Federation in 2014 are presented on Figure 1.

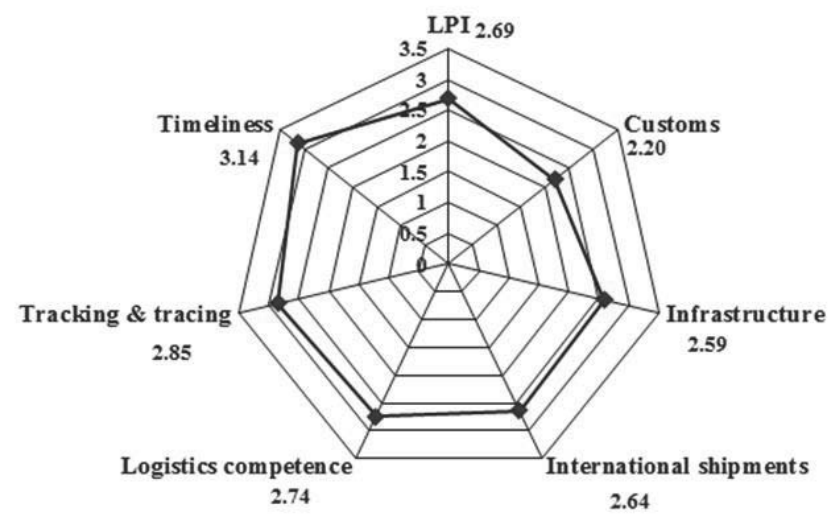

Figure 1: The Main Indicators of LPI Index of the Russian Federation in 2014.

As we can see from Figure 1 currently the level of customs services produces the most negative influence on the general level of efficiency of logistics provision of the foreign economic activities of the RF.

International trade as the part of foreign economic activities can be viewed as a constantly or periodically resumable flow process of transporting goods produced at an enterprise in one country to an enterprise or consumer of another country. As we know flow processes management is the task of logistics - the modern direction of science and practice. Organization of foreign economic activities is now impossible without the active use of logistics.

The classical process of supply and delivery of produced goods to the consumer is transformed in a specific kind of activities because the producer and the consumer belong to different countries; there are borders, customs barriers and other barriers on the way of export-import commodity flows and there is a necessity to overcome them in compliance with the legislation. As a result, logistics and customs activities are closely connected. It demands integrative approach to their research and practical use.

Figure 2 represents the scheme of export-import flows. 


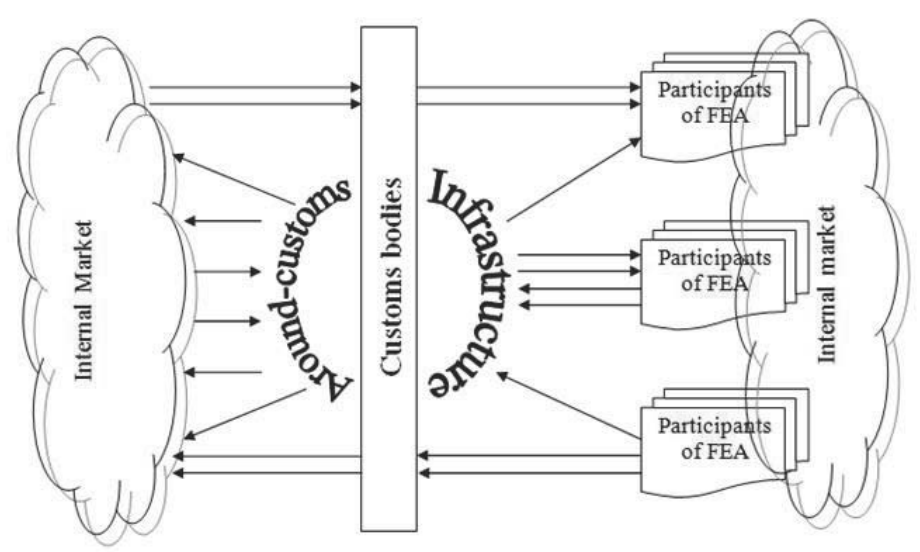

Figure 2 - The Scheme of Export-Import Flows.

The participants of foreign economic activities represented on the scheme are the subjects of the internal market and interact with the external market by making import or export deals. But some large companies make import and export operations simultaneously. As a result the volume of work on the organization of customs clearance of foreign trade cargoes is increased considerably.

When passing the customs formalities the participants of foreign economic activities can interact with the customs bodies directly or via professional mediators that form around-customs infrastructure aimed at the provision of effective overcoming of customs barriers between internal and external markets.

As the economy is being globalized the logistics approach to the organization of foreign economic activities is becoming more and more important. The necessity to comply with all the procedures and rules stated in the corresponding normative and legal acts of the customs legislation is characteristic for the logistics approach. At the same time customs services is the essential element of successful formation of logistics channels and chains of foreign economic activities. So, it seems expedient to name Customs Logistics a separate direction of scientific research.

Customs Logistics studies customs and logistics activities from scientific and practical point of view and unites them into a single state and economic sphere. Foreign trade commodity flow is the main object of the Customs Logistics. It unites the movement of export and import cargoes which cross the customs border. So, customs clearance corresponding to the terms of delivery is needed. Within the frame of logistics component of the customs activities there is integration of the main financial, analytical, information, tariff-regulating, control functions of the customs bodies and there coordination with the interests of the participants of foreign economic activities.

\subsection{Multi-level Approach to the Organization of the Customs Servicing of Foreign Economic Activities.}

Customs logistics system is an integral complex economic system including sections closely connected with each other in the single process of foreign trade commodity flows management. At the same time all these elements in the system are different both in their goals and the type of activities. The functioning of the system provides harmonization of differently directed interests of the state, business and regions.

The economic space of such systems functioning is the sphere of customs activities characterized by complicated organization and heterogeneous composition.

The form of organization of customs logistics activities is the creation of systems with micro-, mezo-, macro- and megalevels.

The formation of the microlevel of organization of activities in customs sphere is made by uniting interacting enterprises-participants of foreign economic activities and customs bodies represented by customs posts.

Macrolevel includes the state level of organization and management of customs activities. The national customs system is the result of the customs policy of the state and is defined as the totality of forms, means and methods of the state regulation of export-import activities.

On the mezolevel the system of customs bodies is represented by the regional customs bodies and local customs. 
At present there are 50 customs offices united into 11 regional customs bodies in the structure of the RF customs bodies. Their most important task is to realize the policy of the state in the sphere of organization of customs servicing of foreign trade activities. The customs offices can be classified according to the character of their activities. They can be divided into external and internal (on the borders of special economic zones). They can also be divided into customs of destination and customs of departure. They organize the work on customs clearance, tracking of export-import goods, etc.

Besides customs bodies specialized companies performing around-customs servicing of the participants of foreign economic activities function on mezolevel. These companies perform different operations and solve different problems but the common goal of their functioning is to perform the most difficult work on the fulfillment of customs requirements to the foreign economic activities of the enterprises-participants of foreign economic activities.

On the other side performing such services provides the increase of quality and successfulness of work of the customs bodies. The existence of around-customs infrastructure makes easier and optimize the interaction of enterprises-exporters and enterprises-importers with the customs bodies providing its multivariant character.

Thus for the successful organization of foreign trade activities it is necessary to integrate enterprises performing export-import operations, customs bodies and professional customs mediators in a single customs logistics system. The multilevel approach to the organization of customs services on the state scale is represented on Figure 3.

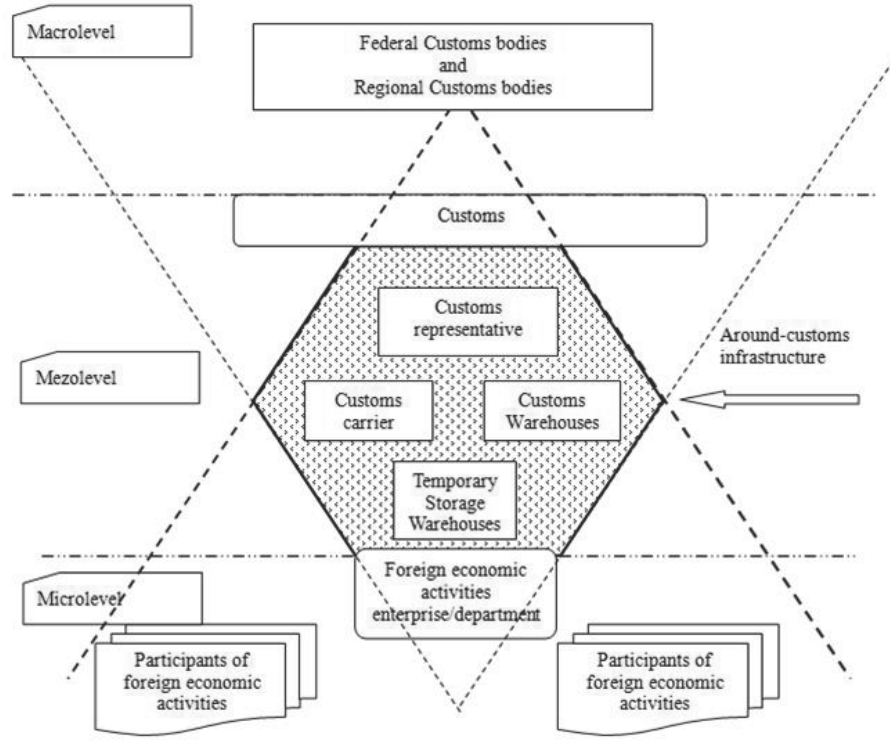

Figure 3 - Multilevel Approach to the Organization of Customs Services

Two oppositely directed triangles on the figure illustrate the interaction of the subjects of customs activities sphere of macrolevel and microlevel. The central customs bodies influence each participant of foreign economic activities (descending triangle) via customs mezosphere guided by the interests of the state.

In its turn ascending triangle demonstrates the consolidation of interests of the participants of foreign economic activities formed on the microlevel and oriented towards the improvement of the customs services system.

In practice enterprises-exporters and enterprises-importers interact with the lower sections of the customs system which do not participate in the development of the customs administration. In their turn the subjects of around-customs infrastructure functioning on the mezolevel and having contacts with a large number of enterprises-participants of foreign economic activities can unite their interests and work out progressive mechanisms of customs services taking into consideration the existing rules and norms. The decisions on changing rules and norms and the improvement of the whole system are taken on the macrolevel, so the important task is the development of institutes representing the interests of business-structures in foreign economic activities. 


\section{Discussion}

At present in scientific literature as well as in practice customs services mean first of all the activities of the customs bodies. For example, Grainger A in his work Customs and Trade Facilitation: from Concepts to Implementation points out that the most important function of the customs bodies is "simplification and harmonization of international trade" where trade procedures mean "activities, methods and formalities connected with collection, representation, processing and transferring of data necessary for transportation of goods in international trade" (Grainger A., 2008).

In the OECD research it is pointed out that customs and administrative procedures have significant impact on the international trade. In some works it is highlighted that for the number of the developing countries the main obstacles on the way to the increasing of the volume of commodity circulation in the international trade are burdensome customs and administrative procedures (Wilson, 2007).

At the same time not enough attention is made the activities of professional customs mediators. Their activities are aimed at the effective interaction of the participants of foreign economic activities and customs bodies and correspondent decreasing of time and financial expenditures during the process of foreign trade activities.

Interaction with customs bodies is one of the most important moments in the work of any company engaged in foreign economic activities. Only large foreign trade corporations can afford having a specialized department dealing with the customs offices. But currently even such corporations prefer to use the services of mediators.

The services of mediators (customs brokers) are now the most widely-spread and called-for among all the services in the customs sphere. Such approach is characteristic for the foreign research works, for example, in the work Customs Brokerage Services and Trade Facilitation: A Review of Regulatory Coherence the author highlights the importance of work of customs brokers both for the state and the business environment.

The interaction of the customs bodies and professional customs mediators takes place on the mezolevel that stipulates the importance of further research of the mezosphere of customs services.

\section{Conclusion}

Thus, the use of multilevel approach to the research of the system of customs services in the sphere of foreign economic activities allows us to make a conclusion that the mezolevel of the customs activities sphere is very important.

Among the subjects functioning on the mezolevel there were singled out professional customs mediators providing effective interaction of the participants of foreign economic activities and customs bodies.

We think it will be optimal for the development and improvement of foreign economic activities to unite customs bodies and professional customs mediators into a single mezosystem of customs services.

The result of functioning of such mezosystem must be the increase of the volume of foreign trade commodity circulation, cutting of expenditures of companies performing export-import operations, the correspondent increase of their competitiveness and the development of the region and the state in general.

\section{References}

Customs in the 21st century: Enhancing Growth and Development through Trade Facilitation and Border Security. electronic text data. World Customs Organization mode of access (2008). http://www.wcoomd.org/en/topics/key-issues/ /media/3EE76BC165B 9409 CBE6E31F9923CABB8.ashx

Doing business. Measuring Business Regulations: Trading Across Borders. The World bank (2014). http://www.doingbusiness.org/data/ exploretopics/trading-across-borders

Evans C. (2003). Studying the Studies: An Overview of Recent Research into Taxation Operating Costs // E-journal of Tax Research, Volume 1, Number 1, 2003. http://www.asb.unsw.edu.au/research/publications/ejournaloftaxresearch/Documents/full_edition_ v1n1.pdf\#page $=64$

Fedorenko, R. V. (2014). Development of Outsourcing in the Customs Sphere. Asian Social Science; Vol. 10, No. 20; 2014, pp.202209.

Grainger A. (2008). Customs and Trade Facilitation: From Concepts to Implementation. World customs journal. 2008. Volume 2. Number 1. p. 17.

Hoekman, B \& Nicita, A (2010). Assessing the Doha Round: Market Access, Transactions Costs and Aid for Trade Facilitation. Journal of International Trade and Economic Development, vol. 9, no. 1, pp. 65-79.

Li, Y \& Wilson, JS (2009). Time as a Determinant of Comparative Advantage, World Bank Policy Research Working Paper WPS5128, November, World Bank, Washington, DC.

Logistics Performance Index. The World Bank (2015) http://lpi.worldbank.org/

Sandford, I \& Temby, I (2010). Customs in the Regional Trade Agreements of Australia and New Zealand: Efforts to Improve Customs 
Instruments and Develop Trade. Global Trade and Customs Journal, vol. 5, no. 11/12, pp. $445-459$.

Wilson, N. (2007). Examining the Trade Effect of Certain Customs and Administrative Procedures. OECD Trade Policy Working Paper No. 42,26 January.

Gupanova Y.E. (2011). Actual Problems of Management of Customs Services. Bulletin of the Russian Customs Academy, № 1. p. 5-12. Ershov A.D., Dolya A.N. (2005). Formation of Customs Services in Foreign Economic Activities // Scientific Notes of the Russian Customs Academy, 2005. № 1. p. 172-180.

Zhigun L.A. (2013). Revealing of the Factors Defining the Quality of the State Customs Services Management. Bulletin of the Russian Customs Academy, 2013. № 3. p. 030-039.

Macconell K.R., Bru S.L. (1992). Economics: Principles, Problems and Politics

Volume1.- M.: Respublika,1992. 